\title{
The Study of Errors and Feedback in Second Language Acquisition (SLA) Research: Strategies used by the ELT practitioners in Bangladesh to address the errors their students make in learning English
}

\author{
Md. Maksud Ali*
}

\begin{abstract}
The study of errors and feedback is one of the major issues in Second Language Acquisition (SLA) research. The research in this area is so important because it gives the English language teaching (ELT) practitioners an opportunity to have an insight in understanding the nature of learners' errors and in giving feedback to learners. Following quantitative method, this paper carries out an empirical cross-sectional survey research on errors and feedback in SLA in the context of Bangladesh in order to generalize the way in which the Bangladeshi ELT practitioners view their students' errors and the ways they correct the errors.
\end{abstract}

Key Words: Second Language (L2) Learners' Errors, Mother Tongue (L1) Interference, Interlanguage, Contrastive Analysis (CA), Error Analysis (EA), Personal Competence, Fossilization, Feedback, Learner Autonomy

\section{Introduction}

The study of errors made by the Second Language Learners (SLL) has been one of the major concerns in Second Language Acquisition (SLA) research. Earlier, it was generally considered that Second language (L2) Learners' errors were the result of mother tongue (L1) interference. However, later there was a reaction against the view and some researchers came up with a new orthodoxy that 'vast majority of errors' were not due to L1 interference but rather they were because of their 'unique linguistic

\footnotetext{
* Lecturer, Department of English Language \& Literature, IIUC.
} 
system' which Selinker (1974) termed as 'Interlanguage'. Interlanguage, though an incorrect form of language, is however, an essential part of L2 learners' language acquisition and language development. Therefore, it is important not merely to view learners' errors and interlanguages positively but to correct them wisely so that they are not fixed in the learners' mind as a fossilized form of language.

The aim of this research is to investigate how the Bangladeshi English Language Teaching (ELT) practitioners view and treat learners' errors in learning English as a Second language (ESL). In so doing, pertinent literature relating to the study of errors and error-correction is reviewed in Section 2. Section 3 outlines the research methodology that is used in this study. In Section 4 research findings are discussed. Finally, Section 5 concludes the paper with research implications and recommendations.

\section{Literature Review}

\subsection{Early perspectives on Error Analysis}

During 1950s and 60s, the general consensus among the behaviourists was that "learners' errors could be predicted by comparing and contrasting the grammars of their L1 and of the target language; where there was difference, there was likely to be errors"'(Benson, 2002, p.68): This process came to be known as Contrastive Analysis (CA). However, during 1970s, CA began to be criticised as to some linguists it appeared that all SLL errors did not originate from L1 (Mitchell and Myles, 1998, p.30). Moreover, in some areas where L1 was supposed to resist errors, CA proved to be less effective; as for an instance, Hernandez-Chavez (1972) shows that though both in English and Spanish plurals are formed almost in the same way, Spanish children learning English as L2 make errors in plural marking (in Mitchell and Myles, 1988). Thus, in the cases where CA seems to fail, as James (1998) remarks, "in its claim to be able to predict errors on the basis of compared descriptions"' (p.5). CA was replaced by a new branch, Error Analysis (EA) which "set out to demonstrate that many learners' errors were not due to learners' mother tongue but reflected universal strategies" (Richards and Schmidt, 2002, p.185). Therefore, views begin to appear, relating to the errors made by SLL that errors themselves are systematic (Corder,1982, p.10) and that L2 learners' performance is 'rule governed' in the same way a native speaker's performance is (ibid, p.66). Apart from this, in their learning process, L2 learners produce some forms of language through their own rule governed system which according to Selinker (1972) do not conform to the target language (TL) to convey the same meaning; the existence of 
The Study of Errors and Feedback in Second Language Acquisition (SLA) Research: Strategies used by the ELT practitioners in Bangladesh to address the errors their students make in learning English

such a 'separate linguistic system', stemming from learners' 'attempted production of TL', is called 'Interlanguage'(IL) (Richards, 1974, p.35).

\subsection{Interlanguage (IL)}

An IL is a kind of language, created by the second and foreign language learners (SLL/FLL) who are in the process of learning a language. This kind of language is like neither L1 nor target language (TL) (Richards and Schmidt, 2002, p.267). The term, IL was first coined by the American linguist, Larry Selinker (1974) to posit that L2 learners develop their linguistic system which is partly based on L1 and yet it is also 'unique' and different both from L1 and L2 (Ellis, 1997, p.33). By late 1970s, EA began to be superseded by the study of IL as Mitchell and Myles (1998) state that "interlanguage studies moved one step beyond Error Analysis by focusing on the learner system as a whole, rather than only on what can go wrong with it"'(p.31). In IL studies, errors are viewed as an essential part of learners' learning activity. It also puts forward the idea that learners' errors are systematic as well as rule governed (Corder, 1982, p.66). Therefore, learners' 'peculiar version' of the TL must be due to their systematic knowledge, which Chomsky terms 'personal Competence' (ibid, p.66).

\subsection{Research on IL Perspective}

To support that L2 learners' IL is rule governed, regardless of what L1 background they belong to, we refer to a secondary research available in the literature. Dulay and Burt (1973 in Mitchell and Myles, 1998, p.32) undertook a cross sectional morpheme study which showed the order in which different children learning English as an L2 from different L1 backgrounds acquired the same grammatical morpheme. The study involved 461 Spanish and 55 Chinese children of various proficiency levels in English; their age ranged from 5 to 9. The study, as mentioned earlier, was cross-sectional and the elicitation technique used in the study was 'Bilingual Syntax Measure', a structured conversation, based on cartoons to elicit certain grammatical conversation. The result of the study indicated a similar acquisition or a clear 'hierarchy' for the children in the acquisition of Brown's thirteen original morphemes although these children belonged to different proficiency levels and different L1 backgrounds.

Later, Bailey, et al. (1974 in Mitchell and Myles, 1998, p.33) replicated the same study with adults, using the same method and technique of elicitation to measure production accuracy on eight morphemes investigated by Dulay and Burt (1973). The study included 73 adult learners of English as L2 from different L1 backgrounds. Their age ranged between 17 and 55. The result of the 
study was found almost similar to that found in the case of the children investigated by Dulay and Burt (1973).

The aforesaid studies indicate that the errors and the IL made by the SLL are systematic in their own rule governed way. Mitchell and Myles (1998) remark, " "...the existence of such an order suggested that L2 learners are guided by internal principles which are largely independent of their first languages..."' (p.33).

\subsection{Fossilization: Need for Feedback}

Sometimes due to the lack of proper feedback on the 'incorrect linguistic features', the IL becomes fixed in a learner's mind; a process known as fossilization (Richards \& Schmidt, 2002). To Selinker (1974), IL performance may be fossilized through five 'central' processes: 'process of language transfer', 'transfer of training', 'strategies of Second language communication', 'strategies of second language learning' and 'overgeneralization of TL linguistic materials' (Richards, 1974, p.37). He further argues, "these five processes are processes which are central to second language learning, and that each process forces fossilizable material upon surface IL utterances, controlling to a very large extent the surface structure of these utterances"'(ibid, p.37). Selinker (1974) thinks, not merely an individual L2 learner but the whole group of L2 learning community may fossilise surface structures which result in the emergence of a new dialect, for example, Indian dialect, "where fossilised IL may be the normal situation"(ibid, p.38). Thus, it is important that learners' interlanguage is addressed with proper feedback so that they are not fossilized with the incorrect linguistic forms.

\subsection{Issues in Addressing Learners' Errors}

In this subsection, we will focus on some of the ways available in the literature which ELT professionals may apply while treating SLL errors. Broadly speaking, what follow are some pedagogical implications that English as a second/foreign Language (ESL/EFL) teachers may apply in an ESL/EFL classroom.

First of all, how teachers view learners' errors is substantially significant. Teachers should view learners' errors positively. To Corder (1982, p.66), errors are an essential part of learning process; they provide teachers with an insight into what kind of feedback the learners may require and what strategies to be taken for the appropriate correction of the learners' errors. 
The Study of Errors and Feedback in Second Language Acquisition (SLA) Research: Strategies used by the ELT practitioners in Bangladesh to address the errors their students make in learning English

Teachers need to have an insight into the reasons behind learners' errors. According to Corder (1982), teachers must be able to identify learners' difficulty for they can help learners only when they realize 'why' they are making errors. He also argues only classifying errors into some artificial groups such as errors of commission or omission, wrong sequence, and wrong selection is not sufficient (p.52). He further claims that "it is important that teachers should be able not only to detect and describe errors linguistically but also understand the psychological reasons for their occurrence' '(p.35). If teachers re-teach learners without realizing the nature of their errors, it may not help the learners, as Corder (1982, p.52) suggests, "re-teaching as a remedial procedure is so often unproductive"'.

In addition, teachers are required to understand a particular situation in which whether or not learners' errors should be corrected. If teachers always find faults with what learners produce and correct them immediately, it may demotivate learners. According to Allright (1975), "learners' errors should be corrected if learners cannot correct themselves" (as quoted by Makino, 1993, p.337). Corder (1982) as well posits "one of the most important tasks of a teacher in language classroom, and it is part of the skilled technique of the teacher to decide when correction is necessary..." (p.65). Allright (1975) and Long (1977) claim that teachers should not correct the errors immediately; rather giving clues (i. e., use of codes) to learners will be more useful for them to activate their linguistic competence and correct their own errors (in Makino, 1993, p.340).

In order to facilitate learning, language teachers ought to try to make learners as autonomous as possible. This is so urgent for learners because it helps them in self-repairing their own errors, and activates their linguistic competence (Makino, 1993, p.338). In the classroom teachers can expose learners to the use of TL produced by the native speakers of the TL and encourage autonomous study which will 'help learners notice their own L2 use in comparison to the use of the TL by native speaker'' (Vickers and Ene, 2006, p.110).

Doughty and William (as quoted by Vickers and Ene, 2006, p.110) argue that one of the major issues in Focus on Form (FonF) research is "how to lead learners' attention to a linguistic mismatch" between IL and TL. It is documented that "the recognition of this mismatch between learners' IL and TL promotes language learning".

\section{Research Design}

This cross-sectional survey research is aimed at exploring the Bangladeshi ELT practitioners' attitudes and strategies towards 
English as a second language (ESL) learners' errors. The study addresses the following research questions:

1. How important is it to correct ESL learners' linguistic errors?

2. How do the ELT practitioners in Bangladesh react to the learners' errors?

3. What are the strategies the Bangladeshi ELT practitioners use in correcting ESL learners' errors?

The survey consisted of a questionnaire which aimed at producing quantitative data. The participants were sampled from the ELT practitioners in Bangladesh, practicing at different levels: primary, secondary, higher secondary levels. Some twenty people were sampled out of which nine respondents returned the questionnaire along with their consent to participate in this study. All the respondents in this research had an MA in ELT from a Bangladeshi university.

SPSS was used to analyze research data so that the descriptive statistics for the data gathered could be produced. The findings of this research are discussed in relation to the literature review section in order that the treatment of the Bangladeshi ESL learners' errors may be compared with those suggested in the literature.

\section{Research Findings and Discussion}

\subsection{Importance of Error Correction}

\begin{tabular}{|c|c|c|}
\hline Statis & & \\
\hline Impor & ice of correction & \\
\hline & Valid & 9.0000 \\
\hline & Missing & .0000 \\
\hline & Mean & 1.8889 \\
\hline & Median & 2.0000 \\
\hline & Mode & 2.0000 \\
\hline & Std. Deviation & .9280 \\
\hline
\end{tabular}

Table 1: Descriptive Statistics- Need for error correction

From the statistics (see Table 1), it appears most of the teachers believe that learners' linguistics errors correction is an important issue. As observed from the test results, $56.6 \%$ respondents view that leraners' ESL error correction is important.The result shows a maximum tendency towards the variable, 'Important' (numerically coded as 2); for example, the mean is 1.88 , median is 2.00 and mode is 2.00 . From the 
The Study of Errors and Feedback in Second Language Acquisition (SLA) Research: Strategies used by the ELT practitioners in Bangladesh to address the errors their students make in learning English

analysis of the data it can also be seen that 33.3\% participants view error correction as 'Very Important' (Numerically coded as 1).

However, $11.1 \%$ of practitioners believe that learners' errors correction is less important.

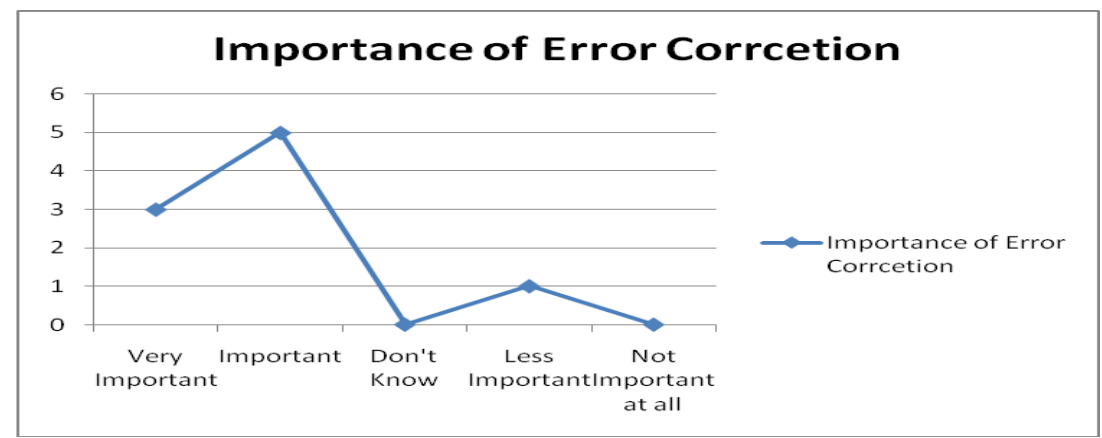

Figure 1: Importance of Error Correction

From the above results, it may be posited that most respondents think learners' ESL errors correction is necessary. This finding corresponds to the existing ELT literature, discussed in the literature review (cf., Section 2). From the findings both of the secondary research (i. e., Literature Review) and this empirically carried out original research, the first resaerch question may have the answer that learners' ESL error correction is important.

\subsection{Teachers' Reaction to the Learners' ESL Errors}

The test results in Table 2 show a clear tendency towards the variable, 'Delighted' (numerically coded as 4); see, for example, the mean in the descriptive statistics table which is 4.444 (also see the median and mode which are respectively 4.00). The result indicates the fact that the ELT practitioners in Bangladesh have tolerance for the errors made by their students. It may thus be conceived that these teachers may believe that learners' errors are indeed part of their learning process.

\begin{tabular}{|l|l|l|}
\hline \multicolumn{2}{|l|}{ Statistics } \\
\hline \multicolumn{2}{|l|}{ Teachers' reaction } & \\
\hline \multirow{4}{*}{$\mathrm{N}$} & Valid & 9.0000 \\
\cline { 2 - 3 } & Missing & .0000 \\
\cline { 2 - 3 } & Mean & 4.4444 \\
\cline { 2 - 3 } & Median & 4.0000 \\
\cline { 2 - 3 } & Mode & 4.0000 \\
\cline { 2 - 3 } & Std. Deviation & .5270 \\
\hline
\end{tabular}

Table 2: Descriptive Statistics: Teachers' reaction to learners' errors. 
As it can be seen from Table 2 and Figure 2, most teachers (56.6\%) do not feel irritated or angry if their learners' make any errors in ESL. However, $44.4 \%$ of the practitioners are shocked (numerically coded as 5) when their students make errors in their learning process. This again creates an impediment to the suggestion that all the ELT practitioners hold a positive view on the learners' linguistic errors.

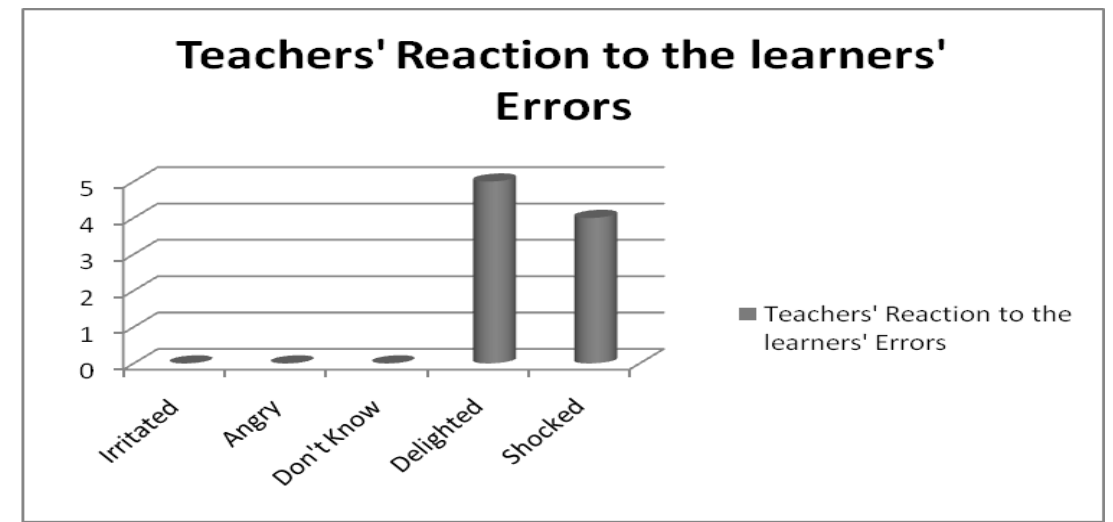

Figure 2: Teachers' Reaction to the Learners' Errors.

In the literature review section, it may be observed that holding a positive attitude towards learners' ESL errors is a priory for the development of learners' linguistic and communicative competence. In the context of Bangladesh, as this research finding shows, most ELT practitioners view learners' errors positively. However, there are also considerable exceptions which indicate the need for further research on this issue on a large scale, which could testify to the validity of this small scale research finding for this research question.

\subsection{Strategies Used in Correcting Learners' Errors}

\begin{tabular}{|l|l|l|}
\hline \multicolumn{2}{|l|}{ Statistics } \\
\hline \multicolumn{2}{|l|}{ Teachers' strategy of correction } \\
\hline \multirow{3}{*}{$\mathrm{N}$} & Valid & 9.0000 \\
\cline { 2 - 3 } & Missing & .0000 \\
\cline { 2 - 3 } & Mean & 2.4444 \\
\cline { 2 - 3 } & Median & 2.0000 \\
\cline { 2 - 3 } & Mode & 2.0000 \\
\cline { 2 - 3 } & Std. Deviation & 1.5092 \\
\hline
\end{tabular}

Table 3: Descriptive Statistics: Strategies in correcting ESL errors. 
The Study of Errors and Feedback in Second Language Acquisition (SLA) Research: Strategies used by the ELT practitioners in Bangladesh to address the errors their students make in learning English

22.2\% ELT practitioners in Bangladesh correct their learners' errors crossing out the errors with red-ink pen, compared to $55.6 \%$ teachers who use a 're-teaching' strategy in correcting the learners' errors. However, $22.2 \%$ practitioners encourage their students to self-correct their errors.

From the analysis of the data it may be seen that the test result shows a clear tendency towards the variable, 'Re-teaching' (numerically coded as 2). Also, the mean is 2.44 , the median is 2.00 , and the mode is 2.00 (See Table 3), which indicate that majority of the ELT teachers in Bangladesh use the 're-teaching' strategy as a means of correcting their students' ESL errors.

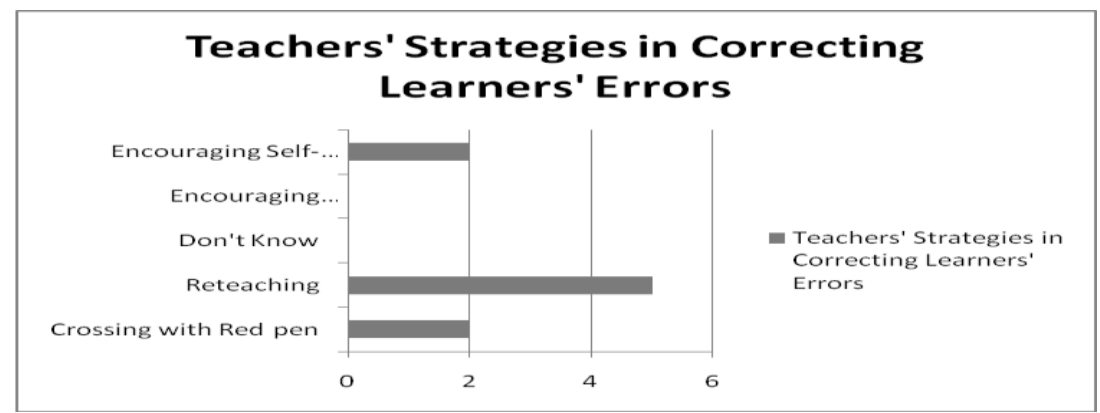

Figure 3: Strategies in correcting learners' errors

A comparative study between the research findings in this section and the literature review suggests a mismatch between the way ELT practitioners in Bangladesh like to correct the learners' errors and the way error correction has been suggested in the literature. A significant number of ELT practitioners (mean, 2.444) like to use 're-teaching' strategy in correcting their students' errors even though it has been suggested in the literature that 're-teaching' as a means to correct learners' errors is often unproductive.

\section{Conclusion}

Most English language teaching practitioners in Bangladesh consider learners' error correction as an important issue in ELT education. The findings also imply that although the ELT practitioners in Bangladesh have empathy for learners' linguistic errors, most of them seem to lack an insight into using a more appropriate correction strategy, such as motivating the learners to 'self-correct' their errors . This may be due to the potential reason that these practitioners perhaps do not have sufficient access to the existing literature and research carried out into ESL errors analysis and feedback. It may also be assumed that the 
training courses (i. e., MA in ELT) that are available in Bangladesh seem to lack a true understanding of the practical application of the theories in the classroom.

The study recommends that the ELT training courses in Bangladesh, as the needs arise, should be revised and redesigned as to be responsive to practical classroom use. We suggest that instead of encouraging a oneway teaching practice, the ELT training courses might encourage the trainees in educational research, reflective and collaborative action research, presentation, observation, developing seminar skills, workshops, etc. In conclusion, the ELT courses in Bangladesh should stimulate rather than force the teachers and engage them in active teaching and action research rather than encourage them to be a group of passive agents.

\section{References}

1. BENSON, C. (2002). Transfer/ Cross-linguistic influence. ELT Journal, 56 (1), pp. 68-70

2. CORDER, S. P. (1982). Error Analysis and Interlanguage. Oxford University Press

3. ELLIS, R. (1997). Second Language Acquisition.Oxford University Press.

4. JAMES, C. (1998). Errors in Language Learning and Use. London: Longman

5. MITCHELL, R and MYLES, F. (1998). Second Language Learning Theories. London: Arnold

6. MAKINO, T-Y. (1993). Learner Self- Correction in EFL Written Compositions. ELT Journal, 47 (4), pp. 337-341

7. RICHARDS, J. C. (1974). Error Analysis: Perspective on SLA. London: Longman

8. RICHARDS, J.C and SCHMIDT, R. (2002). Longman Dictionary of Language Teaching and Applied Linguistics. London: Longman

9. SELINKER, L. (1974). Interlanguage. In Richard. J. C. (Eds.) Errors Analysis: Perspectives on SLA. London: Longman.

10. VICKER, C. H and ENE, E. (2006). Grammatical accuracy and learner autonomy in advanced writing. ELT Journal, 60 (2), pp. 109-116 